\title{
Drivers of the Ceratium hirundinella and Microcystis aeruginosa coexistence in a drinking water reservoir
}

\author{
István Grigorszky 1,2,*, Keve Tihamér Kiss², László József Szabó1, György Dévai ${ }^{1}$, Sándor \\ Alex Nagy¹, Imre Somlyai ${ }^{1}$, Csaba Berta1 ${ }^{1}$, Marija Gligora-Udovič³ ${ }^{3}$ Gábor Borics², Gabriella \\ Pór ${ }^{4}$, Yaqoob Majd Muwafaq ${ }^{1}$, Arber Hajredini ${ }^{1}$, Uyanga Tumurtogoo ${ }^{1}$ and Éva Ács ${ }^{2}$ \\ ${ }^{1}$ University of Debrecen, Department of Hydrobiology, H-4032 Debrecen, Egyetem tér 1., Hungary. \\ 2 Hungarian Academy of Sciences, Centre for Ecological Research, Danube Research Institute, H-1113 Buda- \\ pest, Karolina út 29-31., Hungary. \\ ${ }^{3}$ University of Zagreb, Faculty of Science, Department of Biology Rooseveltov trg 6, 10000 Zagreb, Croatia. \\ 4 Paterson Johal Consulting, \#203B - 10190 152A Street, Surrey, BC, V3A 1M8 Canada. \\ * Corresponding author: grigorszky.istvan@science.unideb.hu
}

Received: $12 / 03 / 18 \quad$ Accepted: $16 / 11 / 18$

\begin{abstract}
Drivers of the Ceratium hirundinella and Microcystis aeruginosa coexistence in a drinking water reservoir

The spatial and temporal patterns of phytoplankton in relation to physical and chemical properties were studied in a drinking water reservoir - the Lázbérc Reservoir - located in north-east Hungary. The main objectives were to determine the role of the hydrologic regime in structuring algal growth and the effects of physical and chemical variables on the coexistence of a dominant species: cyanobacteria, Microcystis aeruginosa (Kützing) Kützing and an eukaryotic dinoflagellates, Ceratium hirundinella (O.F. Müller) Dujardin. The results suggest that nutrients (TP, $\mathrm{NH}_{4}-\mathrm{N}$ and $\mathrm{NO}_{3}-\mathrm{N}$ ), turbidity, and the hydrologic regime play an important role in regulating the occurrence of investigated species. The rainy summer period resulting in a mixing of the water column, and the low level of nitrogen coupled with the internal release of phosphorus from the lake sediment under brief periods of anoxia promote cyanobacterial bloom.

During this period, the water column was characterised by high turbidity, which created favourable conditions for developing a huge $C$. hirundinella biomass and the simultaneous occurrence of $M$. aeruginosa. This study also demonstrated - that contrary to what was previously known, deep standing waters in the temperate zone are not only dimictic (mixing twice a year during the spring and the fall), but they can also be mixed during the summer period due to continued rainfall, which equalizes the temperature in the whole water column. This can promote the occurrence of cyanobacterial and eukaryote planktonic organisms.
\end{abstract}

Key words: Microcystis aeruginosa, Ceratium hirundinella, phosphorus, seasonal variation, water management, lake-polymixis in temperate zone

\section{RESUMO}

\section{Efeito da flor de Ceratium hirundinella $e$ Microcystis aeruginosa no reservatório de água potável}

Os padrões espaciais e temporais do fitoplâncton e sua correlação com as especificidades variáveis físicas e químicas, foram examinados no nordeste da Hungria, localizados em um reservatório típico de água potável no reservatório de Lázbérc. Nosso principal objetivo foi para esclarecer o papel da hidrologia, e os diferentes especificidades físicas e químicas na coexistência de espécies dominantes: cianobactéria, Microcystis aeruginosa (Kützing) Kützing e Dinoflagellata eucariótica, Ceratium hirudinella (OF Müller) Dujardin. De acordo com os resultados, os nutrientes (TP, $\mathrm{NH}_{4}-\mathrm{N}, \mathrm{NO}_{3}-\mathrm{N}$ ), turbidez e os condições hidrológicas desempenham um papel importante na regulação da ocorrência das espécies examinadas. O periodo de verão chuvoso que resulta um equilibrio do nível da água, o baixo nivel de nitrogênio, juntamente com a liberação interna de fósforo do sedimento, durante um curto período anóxico promove a floração de cianobactérias. Durante este período, a coluna de água foi caracterizada por alta turbidez, criando condições favoráveis para o surgimento de uma enorme expansão da biomas- 
sa C. hirundinella e a aparição simultânea de $\mathrm{M}$. aeruginosa. Este estudo mostrou também que as águas profundas nas áreas da zóna moderada, não tem apenas dimictic especialidade (misturando duas vezes por ano, na primavera e no outono), mas também durante a estação do verão pode ser misturada por chuvas contínuas que compensam a temperatura em toda a coluna da água. Isso ajuda a presença de cianobactérias e organismos eucariotas planctônicos.

Palavras chave: Microcystis aeruginosa, Ceratium hirundinella, fósforo, variação sazonal, manejo da água, lago-polimixis em zona temperada

\section{INTRODUCTION}

Over recent years it has become clear that eutrophication is a significant problem in many freshwater reservoirs used as drinking water supply. Eutrophication includes high levels of chlorophyll- $a$ (Boynton et al., 1982; Nixon \& Pilson, 1983; Conley \& Malone, 1992), excessive macrophyte biomass and algal blooms, the occurrence of anoxia and hypoxia (Gerlach, 1990), and harmful and toxic algal blooms (Franks, 1997; Seda et al., 2000; Oudra et al., 2002; Jeppesen et al., 2015).

The understanding of the factors behind the abundance patterns of microbial species in nature are a central issue in environmental sciences. Planktonic microorganisms, as the primary producers, can mirror changes in aquatic ecosystems and carry the basic information needed to assess the trophic status and water quality of aquatic environments. In freshwater phytoplankton assemblages, it is often observed that the phytoplankton undergoes a series of seasonal changes in individuum numbers and biomass, as well as shifts in composition. Succession has acquired a wide meaning in plankton ecology, covering the pattern of annual development, and the sequential changes in species dominance (Smayda, 1980). Planktonic microorganism development occurs at different temporal scales: eg. short-term variations induced by local weather are driven by stochastic disturbances, while annual variations lead to seasonal succession. Their development is the outcome of the interplay between both internal community-directed processes and external forcing (Kiss, 1996; Reynolds, 2000; Reynolds, 2003), and at the same time, abiotic and biotic factors. Nutrient enrichment often leads to increases in microbial biomass (Jones \& Knowlton, 1993), and in particular cyanobacterial production and dominance (van
Liere \& Walsby, 1982; Izaguirre, 1992; Izaguirre et al., 1998, 2007; Bouvy et al., 2003; Izydorczyk et al., 2009; Noyma et al., 2016).

C. hirundinella is also widespread in lakes and ponds in temperate regions. it is often dominates the warm water period and at times also results in blooms also. (Reynolds 1976, Heaney 1976), However there has been little investigation on its population dynamics in reservoirs. Based on a literature review, $C$. hirundinella is a ubiquitous, relatively large and slow-growing species characteristically found during late summer in reservoirs, and in water bodies with a warm stable epilimnion and low nutrient concentrations (Nicolls et al., 1980; Whittington et al., 2000; Inkel et al., 2001; Pérez-Martinez \& SánchezCastillo, 2001, 2002; Grigorszky et al., 2003). Under these low-turbulence conditions, its ability to undertake significant diel vertical migration enables an optimal exploitation of light and nutrients - two essential resources - whose availability contrasts directly in the vertical dimension during stratification (Heaney, 1976; Heaney \& Furnass, 1980; James et al., 1992; Whittington et al., 2000). The seasonal periodicity of $C$. hirundinella is variable. Pérez-Martínez and Sánchez-Castillo (2001) reported clear winter maxima for an array of Spanish reservoirs, but subsequently further highlighted the variability of its occurrence, as reported in the literature. Notwithstanding its putative advantage at low nutrient levels (Whittington et al., 2000), C. hirundinella also occurs in eutrophic lakes (e.g. Frempog, 1984), and was typified as a component of late-summer phytoplankton associations in oligotrophic, mesotrophic and eutrophic temperate waters (Reynolds, 1996). In South Africa, Ceratium blooms have been recorded in 17 of 57 reservoirs (van Ginkel et al., 2007). Among these reservoirs, blooms occurred in all 
seasons and across the trophic status range. These studies show that $C$. hirundinella is a common organism in different seasons and in different trophic statuses, but no precise explanation is yet available for its occurrence. Furthermore, although the two species $M$. aeruginosa and $C$. hirundinella are frequently found together, accurate explanations for their co-occurrence are still lacking. However, the turbid conditions created by the heavy rain and the wind disturbance may have been more favorable for cyanobacterial growth since some taxa have a greater tolerance for turbid conditions (Kosten et al., 2011). In addition, there may have been a positive feedback in the reservoirs with the increased biovolume of cyanobacteria caused by diel vertical migration promoting more turbid conditions, which in turn, enhanced cyanobacterial growth (Kosten et al., 2011). Presing (1996) found that low light conditions created by cyanobacterial blooms facilitated their persistence. Nuisance cyanobacterial blooms are common in drinking water reservoirs and have been associated with the occurrence of objectionable taste and odor events (Saadoun 1999; Smith et al., 2002). Microcystis aeruginosa is one of the dominant species of cyanobacteria that form surface water blooms in eutrophic lakes and has received much attention as a result of the water management problems associated with its blooms (Dokulil \& Teubner 2000). The distribution and abundance of $M$. aeruginosa are to a large extent affected by factors such as light and nutrient availability acting synergistically with other physical and chemical factors. Nitrogen and phosphorus are generally considered to be the main nutrients for algal growth in temperate standing waters. It has been suggested that the lower ratio between these two nutrients may promote the development of cyanobacterial blooms (Smith, 1983). There is also an interesting theory, accompanied by some investigations that positively buoyant cyanobacteria, such as Microcystis, have an ecological advantage in light-limited waters due to buoyancy regulation (Huisman et al., 2004;). Therefore it is thought that low light and low nitrate concentrations may create conditions more favourable to the dominance of $M$. aeruginosa. However, little information is available about the combined effects of nitrogen, phosphorus concentration, and light intensity on population dynamics and coexistence with other population of $M$. aeruginosa. We conducted a field experiment to evaluate the nutrient concentrations and the hydrological regime in combination with light intensities on the growth/coexistence of $C$. hirundinella and $M$. aeruginosa in a drinking water reservoir. The objectives of this study were to determine (i) temporal and spatial patterns in the relationships between water quality and cyanobacterial and dinoflagellates growth, (ii) the role of the hydrologic regime in structuring cyanobacterial growth and (iii) which variables make it possible for the two dominant taxa, $M$. aeruginosa (cyanobacteria) and $C$. hirundinella (eukaryotic alga, dinoflagellate), to coexist. In addition, we discuss the implication of our results with respect to management strategies for the Lázbérci Reservoir and drinking water reservoirs in general.

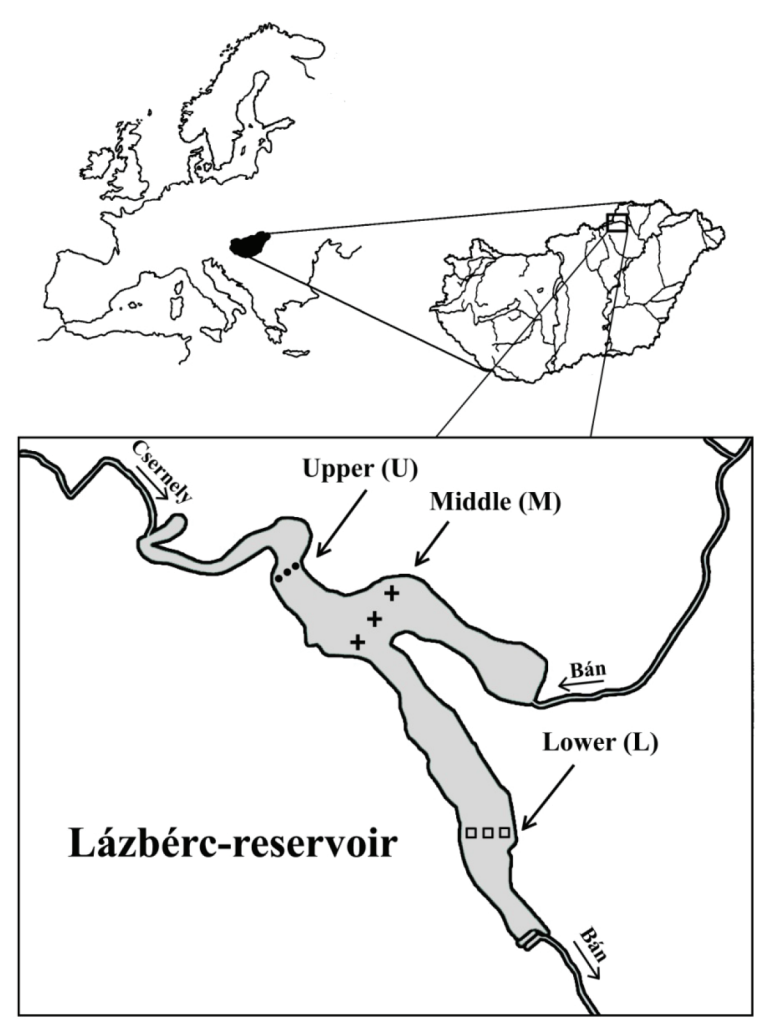

Figure 1. Sampling sites at the studied Lázbérci Reservoir. Locais de amostragem no reservatório de Lázbérc. 


\section{MATERIAL AND METHODS}

Lázbérci Reservoir is located in the North-Eastern part of Hungary, in a low mountain region $\left(48.1226^{\circ} \mathrm{N}, 20.2752{ }^{\circ} \mathrm{E}\right.$, Fig. 1). It was constructed in period between 1967 and 1969 to assure the drinking water supply for the fast-growing region of North-Hungary. The reservoir volume is 5.9 million $\mathrm{m}^{3}$. Its average depth is 7.5 $\mathrm{m}$ and its maximum depth is $17.2 \mathrm{~m}$. The reservoir has a surface area of 77 ha that can be extended to 92.2 ha during flood control operations. The 23.9 $\mathrm{km}$ long Bán Stream and the $17.2 \mathrm{~km}$ long Csernely Stream flow into the reservoir. The retention time of the reservoir is approximately 1 year. The watershed encompasses nearly 217.5 ha. Annual precipitation in the reservoir area was $806 \mathrm{~mm}$ in 2007 and $911 \mathrm{~mm}$ in 2008. The average annual precipitation in Hungary is $500-700 \mathrm{~mm}$. The temperature reached its maximum value in July, in both years. By contrast, wind intensity increased in spring (April-June) and late summer to autumn (September to November). Reservoirs exhibit distinct longitudinal gradients in their physical, chemical, and biological properties due to their "river-lake hybrid" nature. In order to characterize these gradients, nine sampling sites based on lake morphology (i.e., location and depth) were selected and divided into three general categories (upper, middle and lower regions, Fig.1).

Each of the nine sampling sites was sampled monthly from April to November. A 2 L Van-Dorn sampler was used to collect water samples at a series of discrete depths that were determined by the maximum depth at each site (surface $/ 0.25 \mathrm{~m}, 1.5 \mathrm{~m}, 3 \mathrm{~m}, 6 \mathrm{~m}, 9 \mathrm{~m}$ and $12 \mathrm{~m}$ ). Phytoplankton counting was done according to Utermöhl (1931) in an inverted microscope (Axiovert-100). At least 400 units were counted giving a counting accuracy, expressed in terms of $95 \%$ confidence limits of, $<10 \%$ for the whole phytoplankton. The phytoplankton biomass determination was based on the calculation of the species volume.

Samples for $\mathrm{NO}_{3}-\mathrm{N}, \mathrm{NO}_{2}-\mathrm{N}, \mathrm{NH}_{4}-\mathrm{N}$, and $\mathrm{PO}_{4}-\mathrm{P}$ were filtered through ion chromatography acrodisc $0.45 \mu \mathrm{m}$ filters before analysis. Temperature, conductivity, oxygen, $\mathrm{pH}$ were measured when sampling. Total nitrogen (TN) and total

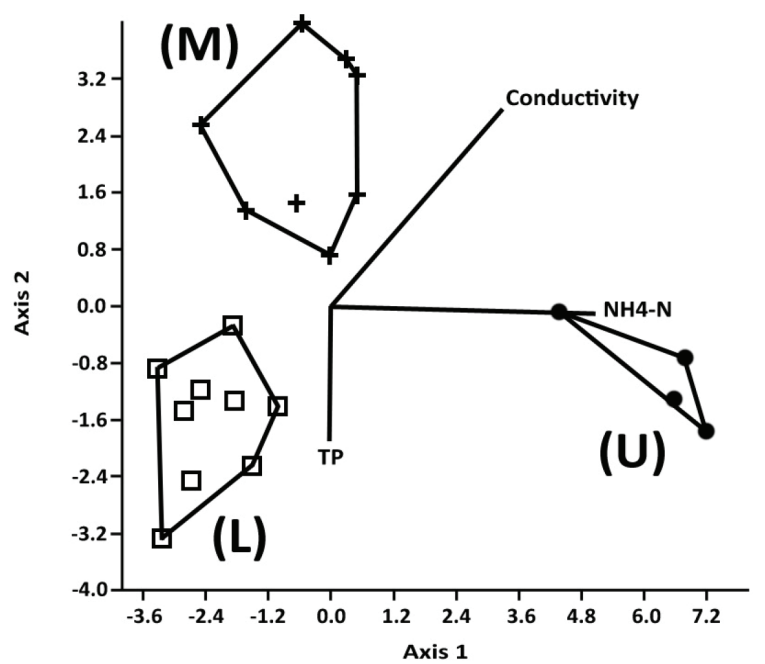

Figure 2. Canonical Variate Analysis (CVA) of the sampling sites in correspondence with environmental variables in Lázbérc Reservoir Canonical Variate 1 was significant $(\mathrm{p}<0.0001)$ and comprised $74.76 \%$ of the total variation. Canonical Variate 2 was also significant $(p<0.0001)$ and comprised $25.24 \%$ of the total variation. $(\bullet=$ no species; $+=C$. hirundinella only; $\square=M$. aeruginosa and C. hirundinella). Análise canônica multivariada (AVC) dos locais de amostragem em ligação de variáveis ambientais do reservatório Lázbérc. A variação canônica 1 foi significativa ( $p<$ 0.0001) e $74.76 \%$ da variação total. A variação canônica 2 também foi significativa $(\mathrm{p}<0.0001)$ e continha $25.24 \%$ da variação total. $(\bullet=$ Nenhuma espécie $;+=$ apenas $\mathrm{C}$. hirundinella; $\square=\mathrm{M}$. aeruginosa $e \mathrm{C}$. hirundinella).

phosphorus (TP) concentrations were determined using photometric procedures (Ebina et al., 1983). The total alkalinity was measured titrimetrically (APHA, 1995). All laboratory analysis was performed within 48 hours of sample collection. The concentration of chlorophyll- $a$, corrected for pheophytin-a, was determined photometrically.

The Shapiro-Wilks test was used to analyze the normality of conductivity, TP and $\mathrm{NH}_{4}$ within the groups. Multivariate normality conditions for the multivariate Canonical Variate Analysis (CVA) were analysed by the Mardin test for conductivity, TP and NH4. Since the latter test gave very similar results to the normal distribution, the upper, middle and lower parts of the reservoir were compared by CVA. The groups were compared with one-way ANOVA and Tukey post hoc (normal distribution) tests, or with the Kruskall-Wallis and Mann-Withney tests (non-normal distribution). 

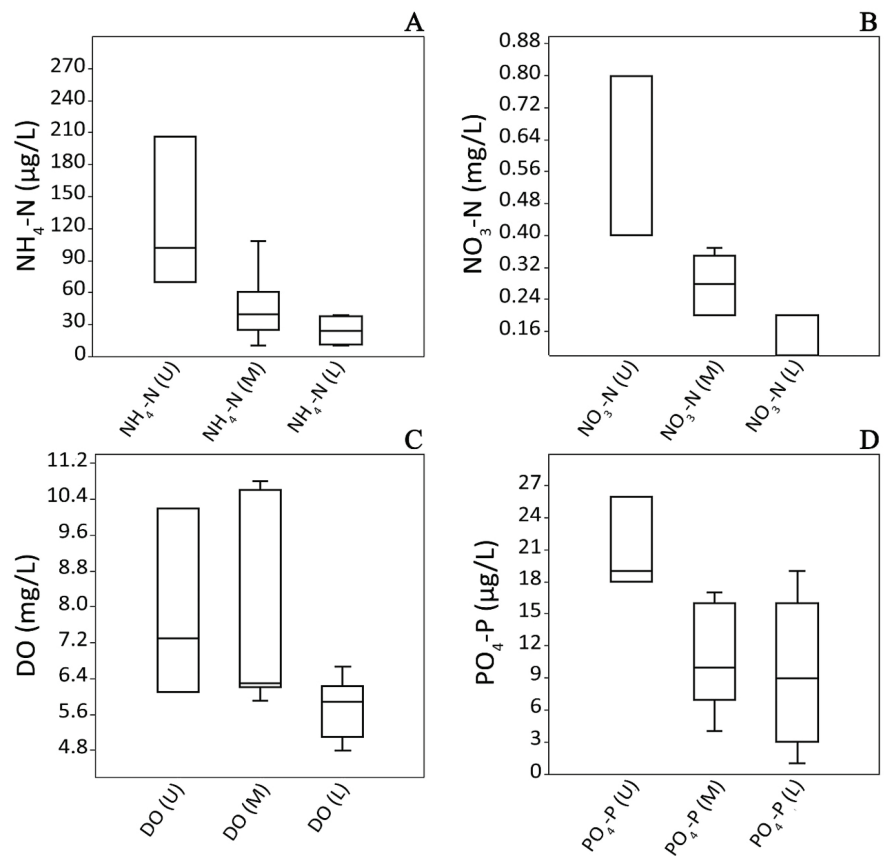

Figure 3. The physical and chemical variables in the various parts of the reservoir $(\mathrm{U}=$ upper region, $\mathrm{M}=$ middle region, $\mathrm{L}=$ lower region): A, $\mathrm{NH}_{4}-\mathrm{N} ; \mathrm{B}, \mathrm{NO}_{3}-\mathrm{N} ; \mathrm{C}$, dissolved oxygen; $\mathrm{D}, \mathrm{PO}_{4}-\mathrm{P}$. Especialidades físicas e químicas estudadas em três regiões do reservatório $\left(U=\right.$ região superior, $M=$ região média, $L=$ região inferior): $A, N_{4} ; B, N_{3}-N$; $C$ oxigénio dissolvido; $D, P O_{4}-P$.

\section{RESULTS}

The CVA of the biomass of M. aeruginosa and $C$. hirundinella as regards to Total Phosphorous (TP), ammonium-ion $\left(\mathrm{NH}_{4}-\mathrm{N}\right)$ and conductivity showed that the studied sites of the reservoir could be divided into three different groups (Fig. 2). Sampling sites, - the upper part of the reservoir, $\mathrm{U}$ - with high concentrations of ammonium-ion correlated with sites where neither M. aeruginosa nor $C$. hirundinella was present. The second group of sampling sites - middle part of the reservoir, $\mathrm{M}$ - was characterized by high conductivity and the presence of $C$. hirundinella only. The third group contained locations - the lower part of the reservoir, L -, where both species were present, and where the principle of separation was based on the low phosphorous content.

Based on the average concentrations of ammonium-ion, nitrate-ion and orthophosphate-ion the sampling sites were split into two groups (Fig. 3). The first group was composed of upper region samples with no presence of $C$. hirundinella or $M$. aeruginosa and with high concentration of the ammonium-ion, nitrate-ion and orthophosphate-ion. The second group represented sites from the middle and lower regions where $C$. hirundinella occurred on its own or sites where both species were found. In the second group the ammonium-ion, nitrite ion and orthophosphate-ion concentrations where low (Fig. 3),

Based on the average concentrations of dissolved oxygen, the sampling sites were split into two groups (Fig. 3C). Higher dissolved oxygen concentrations characterized sites where neither of the two species occurred or sites where C. hirundinella occurred on its own. Lower dissolved oxygen concentrations were measured at sites where both species were found.

Furthermore, we examined the variables that were influential in terms of the co-occurrence of the two species in the lower part of the reservoir, especially concerning the low dissolved oxygen concentrations. In May, dissolved oxygen levels were low $(0-3 \mathrm{mg} / \mathrm{L})$ in the lower regions (below $9 \mathrm{~m}$ depth) of the reservoir (Fig. 4A). In June and 
July, the low oxygen content became characteristic of shallower depths, up to $1.5 \mathrm{~m}$. By September, this low oxygen zone descended again below $3 \mathrm{~m}$, and continued to descend below $9 \mathrm{~m}$ in October. In November, the dissolved oxygen content of the entire water column was significantly higher. In May and June, the orthophosphate-ion concentration was typically low both close to the surface and in deeper water layers (Fig. 4B). The observed ortophosphate-ion concentration increase in June and July was almost characteristic for the entire water column (Fig. 4B). In September, the orthophospate deficient water layer was sank down to a depth of about 4 meters (Fig. 4B), while this layer was characterized by a mass occurrence of the examined species (Fig. 4. C, D). In April and May, C. hirundinella did not occur at any depth (Fig. 4C). In June, there was a minor occurrence of the species at the upper two sampling depths, while it disappeared again in July. In September, the $C$. hirundinella biomass became significant in all three upper sampling depths, reaching the maximum value of the study period at $1.5 \mathrm{~m}(1.6 \mathrm{mg} / \mathrm{L})$. In October, $C$. hirundinella only occurred at the upper two sampling depths with a low biomass.

In April and May, M. aeruginosa did not occur at any depth (Fig. 4D). In June, the species occurred at the $3 \mathrm{~m}$ depth in moderate numbers, which remained the same in July. In September, the biomass of $M$. aeruginosa increased significantly at all depths down to $3 \mathrm{~m}$, reaching the maximum value $(0.8 \mathrm{mg} / \mathrm{L})$ at $1.5 \mathrm{~m}$. The species did not occur in October and November.

In April, water temperature was at its minimum. All layers of water reached their maximum values in July. By this time, the temperature of the near-surface and the $1.5 \mathrm{~m}$ layer was higher
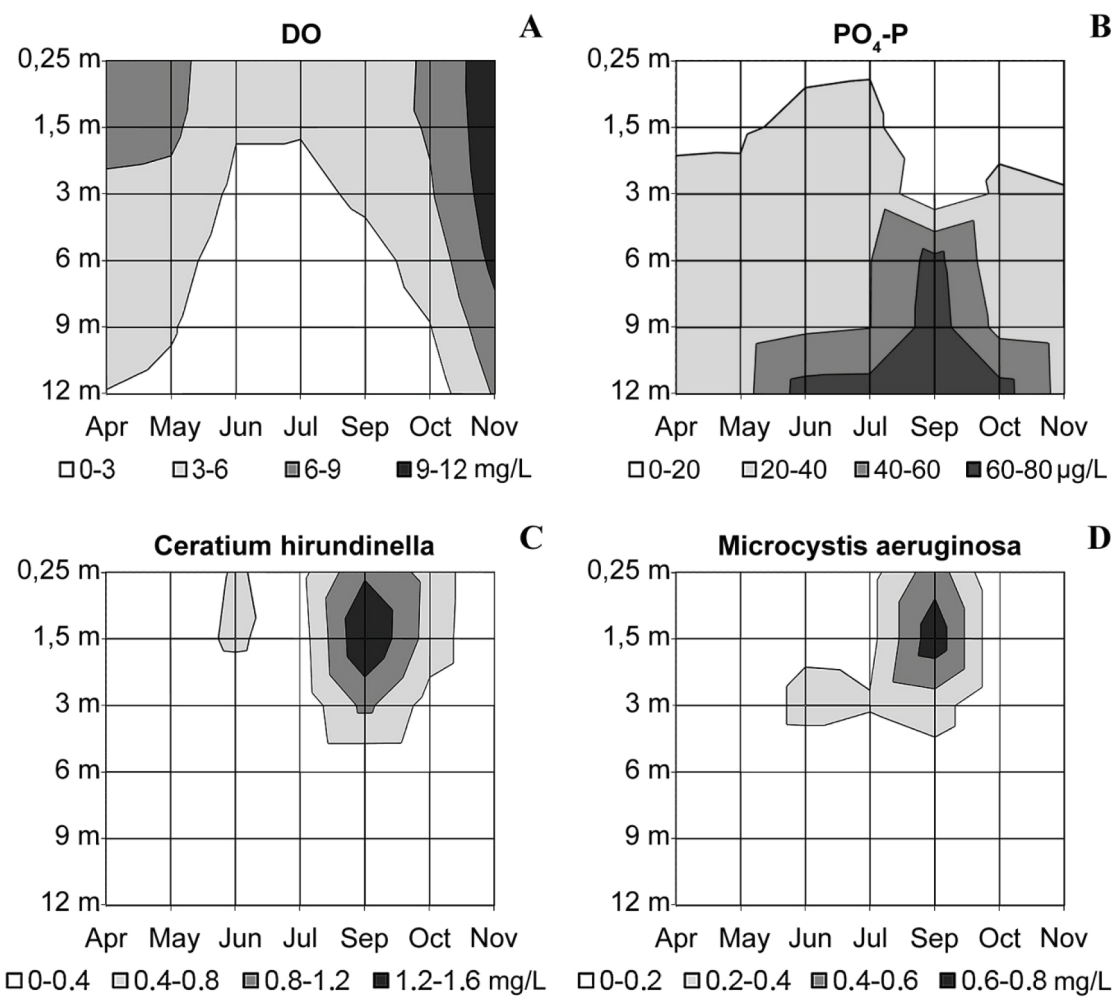

Figure 4. The dissolved oxygen (A), $\mathrm{PO}_{4}-\mathrm{P}(\mathrm{B})$, biomass of $C$. hirundinella $(\mathrm{C})$ and $M$. aeruginosa (D) at various depth in the lower region of the reservoir. O teor de oxigénio dissolvido $(A), P_{4}-P(B), o$ C. hirundinella $(C)$ e o M. aeruginosa $(D)$ biomassa em diferentes profundidades na parte inferior $(L)$ do reservatório. 

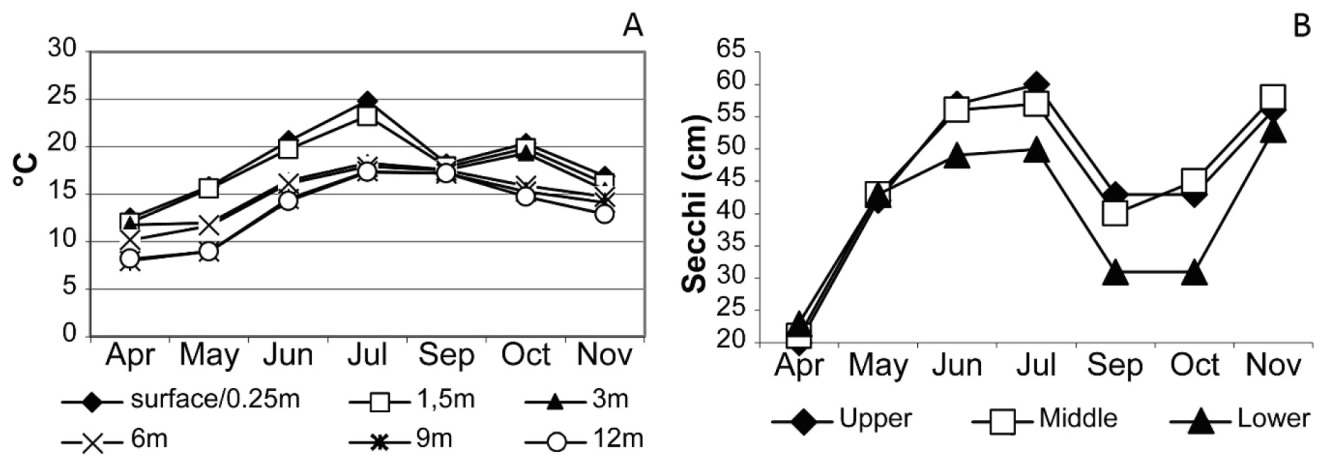

Figure 5. Temperature and transparency changes of the reservoir: A) temperature changes at various depths in the lower region of the reservoir (L); B) Secchi depth changes in the various regions of the reservoir. Mudança da temperatura e transparência do reservatório: A) mudança de temperatura em diferentes profundidades na parte inferior do reservatório (L); B) mudanças de profundidade de Secchi em diferentes áreas do reservatório.

and completely separated from the maximum temperature of the deeper layers. In September, the temperature of all layers decreased markedly to the same value at all layers (Fig. 5A). In October, the water temperature at the surface, at $1.5 \mathrm{~m}$ and at $3 \mathrm{~m}$ started to increase slightly, while it decreased in all the other layers. In November, the temperature of the entire water body decreased to nearly the same value.

The transparency of the water was the lowest in April at all three sampling sites (Upper, Middle, Lower), and then strongly increased in May (Fig. 5B). In June and July, the the transparency of the water at the sampling sites increased, while as a result of rainfall in September it reduced significantly (Fig. 5B). In October, the transparency of the water increased at the middle sampling site, however, while at the upper and lower sites it remained low. The transparency of the water in November increased strongly at all three investigated sites.

\section{DISCUSSION}

Based on our Canonical Variance Analysis (CVA) with the consideration of the chemical variables, it can be observed that the individual sampling sites and the associated two algae species are separated in the reservoir area. The reservoir was divided into three different parts. A discrete group is composed of those samples that originate from the upper part of the reservoir and during the year none of the two species occurred in this region (U). Samples from the middle part of the reservoir were grouped separately, i.e. locations where only $C$. hirundinella occurred (M), and the lower part of the reservoir (L) where the co-occurrence of $C$. hirundinella and M. aeruginosa was typical. The ammonium-ion concentration over the entire year was the highest at the sampling site where one none of the examined species was not occurred. Here we found the greatest change in the ammonium-ion concentration over the investigated period. The annual average of the ammonium-ion concentration was significantly lower at those sampling points where just the $C$. hirundinella has occurred. The lowest ammonium-ion concentration was found at those sampling sites where both investigated species was occurred. Considering the average for the whole year, the concentration of the orthophosphate-ion with the consideration of the whole yearly average was the highest at those sampling sites where none of the studied species were occurred. The annual average of orthophosphate ion concentration was significantly lower at those sampling sites where only $C$. hirundinella occurred. The annual average concentration of the orthophosphate ion was even lower - the lowest at those sampling sites where both two species occurred. Here, the concentration of the orthophosphate ion varied most during the study period. 
Based on our results in a mesotrophic reservoir, we identified an additional process: the lowest parts of the reservoir were characterised by the highest algal biomass, but lower nutrient concentrations, because the large quantities of living organisms used the nutrients and thus the amount of nutrients in the water body decreased.

The characteristic species composition and the community formed by the dominant species of a reservoir depend on meteorological, physical and chemical characteristics. During our study we were able to describe the potential mechanisms facilitating the common cyanobacterial and eukaryotic algal blooms (Fig. 6). We observed increases in algal biomass concentrations in September after a rainy, cold period. During this period, the reservoir experienced a brief period of non-stratification and parts of the hypolimnion became anoxic potentially resulting in the internal release of nutrients from the sediment. As these special hydrological and climatic circumstances allowed phosphorus to move up from the anoxic bottom region to the upper, photic layers, cyanobacterial and eukaryotic algal blooms occurred.

Considerable evidence suggests that nutrient conditions can facilitate the dominance of cyanobacteria. The explanations of the occurrence of Cyanobacteria taxa occurrence are quite obvious if the given Cyanobacteria taxa tend to have a competitive advantage in low $\mathrm{N}$ environments because such taxa are able to fix atmospheric $\mathrm{N}_{2}$. Therefore, our data provides support for the hypothesis that low $\mathrm{N}$ concentrations favour cyanobacterial dominance if the available phosphorus is present. While nutrient concentrations were important in facilitating cyanobacterial development, the hydrologic regime of the lake may also have played an important role in the biomass increase of $C$. hirundinella. There may have been a positive feedback in the reservoir with increased biomass of cyanobacteria and more turbid conditions, which in turn, enhanced C. hirundinella growth.

\section{CONCLUSION}

Ecological communities are expected to be structured by a variety of stochastic and deterministic processes. Two deterministic processes are thought to play a major role in determining the coexistence of species in the same trophic level: interspecific competition and environmental filtering, where species are excluded from a community due to an inability to survive and reproduce in a given physical environment. The general rules for predicting the relative importance of
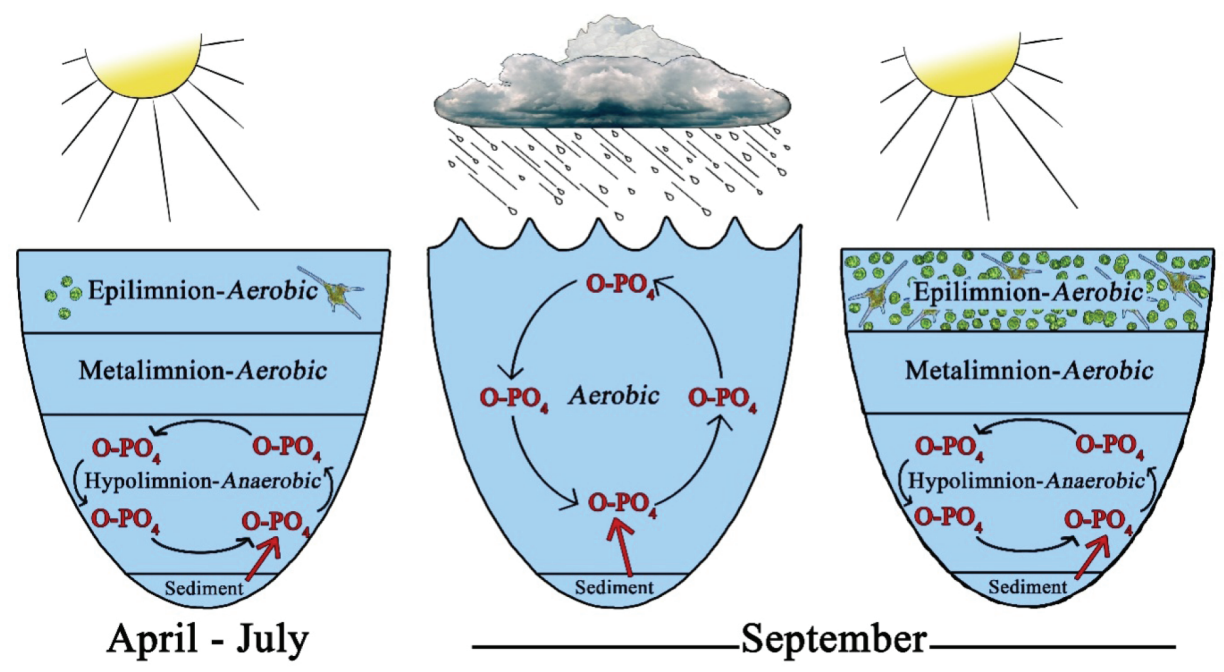

Figure 6. The cyanobacterial and eukaryotic algal bloom forming process in drinking water reservoir. Formação da produção em massa de cianobactérias e algas eukarióticas no reservatório. 
these processes in different contexts are still largely unresolved. The results of this study strongly suggest that there is a positive association between the increase in the frequency of summer rainfall events, the resulting non-stratification and internal P-release, and cyanobacterial blooms. Therefore, identifying the causal factors related to cyanobacterial blooms is an important first step in managing the water quality problems of drinking water reservoirs. Low nitrogen levels in combination with internal phosphorus inputs from the watershed and sediment may have created conditions that were favourable for cyanobacterial production. Furthermore, mixing patterns helped to move up to the phosphorus up into the surface region to promote nitrogen-fixing cyanobacteria growth.

The complexity of the processes involved in the development of algal blooms cannot be completely understood with costly mesocosm or microcosm approaches. Therefore, it is extremely important to study and understand the phenomena that occur naturally in the reservoirs, and then use our experiences as a model on other water bodies. By doing so, we will be able to understand different ecosystem processes that control algal blooms and how they interact and respond to different inputs.

The co-existence of phytoplankton assemblages under similar environmental conditions has allowed the identification of functional groups made up of species with similar morphological and physiological characteristics. Fourteen groups of phytoplankton were identified in Reynolds's original study (Reynolds, 1980a,b). Some have been subdivided since, although the biggest change has been to re-label them (Reynolds, 1984). The Reynold's model includes such group - LM -, which together include the $C$. hirundinella and M. aeruginosa. The model will be redesigned, but these two species will remain in the given group. In some cases, the two species often occur together in large quantities in various types of standing water all over the world. At other times, from year to year one or the other become the dominant species in the same water. In addition, in many respects these two species have extremely different of ecological needs.

Cyanobacteria blooms are typically associated with eutrophic and poorly flushed waters (Paerl, 1988; Paerl et al., 2001; Phieler et al., 2009; Quin et al., 2010; Smith. 1983). As surface waters become enriched with nutrients, particularly phosphorus (P), there is often a shift in the phytoplankton community towards dominance by cyanobacteria (Smith, 1983, Wang \& Wang, 2009, Zhai et al., 2009). The nutrient release from the sediment may have helped to further facilitate cyanobacterial blooms as has been reported in other waterbodies (Forbes et al., 2008, Paerl 2009). Johnston \& Jacoby (2003) also hypothesized that internal nutrient release was an important factor in fueling cyanobacterial blooms in a large lake in Seattle, Washington. Following the period of stratification, the lake began to mix as wind speed and rainfall events increased, and temperature gradients were minimal in the early fall (Wang \& Wang, 2009).

Finally, this study demonstrated that higher temperatures coupled with elevated P concentrations frequently yielded growth rates of toxic Microcystis cells which exceeded all other treatments and populations.

Our study might also be used as a predictive tool supporting inter-disciplinary ecosystem management to assist in previewing the consequences of different management decisions. We suggest that management efforts should focus on controlling mesotrophic/eutrophic reservoirs. Because of the high amount of phosphorus released from the bottom of the water body due to anaerobic conditions, the phosphorus concentrated water needs to be released from the hypolimnion at intervals. This might be especially important during the summer months, before long-lasting rains to prevent undesirable cyanobacterial and/ or algal blooms or mass production.

\section{ACKNOWLEDGEMENTS}

Dear Maria Rosa! Thank you for the wonderful day we got to spend with you and Eduardo in Valencia. We've learned a lot from you and had a very nice experience during our researches. As a person of love and kindness you have already moved to the angels. There will be one more star shining in the sky. Thank you for everything.

The research was financed by the Higher 
Education Institutional Excellence Programme of the Ministry of Human Capacities in Hungary, within the framework of the 4 . thematic programme of the University of Debrecen.

\section{REFERENCES}

ASSOCIATION APHA. 1995. Standard methods for the examination of water and wastewater. Washington, D. C.

BOUVY, M., M. S. NASCIMENTO, R. J. R. MOLICA, M. FERREIRA, V. HUSZAR, \& M. F. O. S. AZEVEDO. 2003. Limnological features in Tapacurá reservoir (northeast Brazil) during a severe drought. Hydrobiologia, 493 (1-3): 115-130. DOI: 10.1023/A: 1025405817350

BOYNTON, W. R., W. M. KEMP \& C. W. KEEFE. 1982. A comparative analysis of nutrients and other factors influencing estuarine phytoplankton production. In: Kennedy VS, editor. Estaurine comparisons. pp. 69-90. Academic Press, New York. DOI: 10.1016/ B978-0-12-404070-0.50011-9

CONLEY, D. J. \& T. C. MALONE. 1992. Annual cycle of dissolved silicate in Chesapeake Bay: implications for the production and fate of phytoplankton biomass. Marine Ecology Progress Series, 81 (2): 121-128. DOI: $10.3354 /$ meps 081121

DOKULIL, M. T. \& K. TEUBNER. 2000. Cyanobacterial Dominance in Lakes. Hydrobiologia, 438 (1-3), 1-12. DOI: 10.1023/A: 1004155810302

EBINA, J., T. TSUTSUI \& T. SHIRAI. 1983. Simultaneous determination of total nitrogen and total phosphorus in water using peroxodisulfate oxidation. Water Research, 17 (12): 1721-1726. DOI: 10.1016/0043-1354(83) 90192-6

FRANKS, P. J. S. 1997. Spatial patterns in dense algal blooms. Limnology and Oceanography, 42 (5): 1297-1305. DOI: 10.4319/1o.1997.42. 5 part 2.1297

FORBES, M. G., DOYLE, R. D., SCOTT, J. T., HUANG, H. \& B. W. BROOKS. 2008. Physical factors control phytoplankton production and nitrogen fixation in eight Texas reservoires. Ecosystems, 11 (7): 1181-1197. DOI: 10.1007/s10021-008-9188-2

FREMPONG, E. 1984. A seasonal sequence of diel distribution patterns for the planktonic Dinoflagellate Ceratium hirundinella in a eutrophic lake. Freshwater Biology, 14 (4): 401-421. DOI: 10.1111/j.1365-2427.1984. tb00163.x

GERLACH, S. A. 1990. Nitrogen, phosphorus, plankton and oxygen deficiency in the German Bight and in Kiel Bay. Kieler Meeresforschungen, Sonderheft, 7: 341.

GRIGORSZKY, I., BORICS, G., PADISÁK. J., TÓTMÉRÉSZ, B., VASAS, G. NAGY, S. \& G. BORBÉLY. 2003. Factros controlling the occurence of Dinophyta species in Hungary. Hydrobiologia, 506 (1-3): 203-207. DOI: 10.1023/B:HYDR.0000008552.60232.68

HEANEY, S. I. 1976. Temporal and spatial distribution of the dinoflagellate Ceratium hirundinella O. F. Müller within a small productive lake. Freshwater Biology, 6 (6): 531-542. DOI: 10.1111/j.1365-2427.1976. tb01644.x

HEANEY, S. I. \& T. I. FURNASS. 1980. Laboratory models of diel vertical migration in the dinoflagellate Ceratium hirundinella. Freshwater Biology, 10 (2): 163-170. DOI: 10.1111/j.1365-2427.1980.tb01190.x

HUISMAN, J., SHARPLES, J., STROOM, J. M., VISSER, P. M., KARDINAAL, W. E. A., VERSPAGEN, J. M. H. \& B. SOMMEIJER. 2004. Changes in turbulent mixing shift competition for light between phytoplankton species. Ecology, 85(11): 2960-2970. DOI: 10.1890/03-0763

INKEL, C. E. van, HOHLS, B. C. \& E. VERMAAK. 2001. A Ceratium hirundinella (O. F. Müller) bloom in Hartbeespoort Dam. Water SA, 27 (2): 269-276. DOI: 10.4314/wsa.v27i2. 5000

IZAGUIRRE, G. 1992. A copper-tolerant Phormidium species from Lake Mathews, California, that produces 2-methylisoborneol and geosmin. Water Science and Technology, 25 (2): 217-223. DOI: 10.2166/wst.1992.0055

IZAGUIRRE, G. \& W. D. TAYLORA. 1998. A Pseudoanabaena species from Castaic Lake, California, that produces 2-methylisoborneol. Water Research, 32 (5): 1673-1677. DOI: 
10.1016/S0043-1354(97)00379-5

IZYDORCZYK, K., C. CARPENTIER, J. MRÓWCZYŃSKI, A. WAGENVOORT, T. JURCZAK \& M. TARCZYŃSKA. 2009. Establishment of an Alert Level Framework of cyanobacteria in drinking water resources by using the Algae Online Analyser for monitoring cyanobacterial chlorophyll a. Water Research, 43 (4): 989-996. DOI: 10.1016/j. watres.2008.11.048

JAMES, W. F., TAYLOR, W. D. \& J. W. BARKO. 1992. Production and vertical migration of Ceratium hirundinella in relation to phosphorus availability in Eau Galle Reservoir, Wisconsin. Canadian Journal of Fisheries and Aquatic Sciences, 49 (4): 694-700. DOI: 10.1139/f92-078

JEPPESEN, E., S. BRUCET, L. NASELLI-FLORES, E. PAPASTERGIADOU, K. STEFANIDIS \& T. NÕGES. 2015. Ecological impacts of global warming and water abstraction on lakes and reservoirs due to changes in water level and realted changes in salinity. Hydrobiologia, 750 (1): 201-227. DOI: 10.1007/s10750-014-2169-x

JOHNSTON, B. R. \& J. M. JACOBY. 2003. Cyanobacterial toxicity and migration in a mesotrophic lake in western Washington, USA. Hydrobiologia, 495 (1-3): 79-91. DOI: 10.1023/A:1025496922050

JONES, J. R. \& M. F. KNOWLTON. 2003. Limnology of Missouri Reservoirs: An analysis of regional patterns. Lake and Reservoir Management, 8 (1): 17-30. DOI: 10.1080/ 07438149309354455

KISS, K. T. 1996. Diurnal change of planktonic diatoms in the River Danube near Budapest (Hungary). Algological Studies/ Archiv für Hydrobiologie, Supplement 80: 113-122.

KOSTEN, S., HUSZAR, V. L. M., BÉCARES, E. COSTA, L. S., VAN DONK, E., HANSSON, L-A., JEPPESEN, E., KRUK, C., LACEROT, G., MAZZEO, N., DE MEESTER, L., MOSS, B., LÜRLING, M., NÕGES, T., ROMO, S. \& M. SCHEFFER. 2011. Warmer climates boost cyanobacterial dominance in shallow lakes. Global Change Biology, 18 (1): 118-126. DOI: 10.1111/j.13652486.2011.02388.x
NICHOLLS, K. M., KENNEDY, W. \& C. HANNET. 1980. Fish-kill in Heart Lake, Ontario, associated with the collapse of a massive population of Ceratium hirundinella. (Dinophyceae). Freshwater Biology, 10 (6): 553-561. DOI: 10/1111/j.1365-2427.1980. tb0131.x

NIXON, S. W. \& M. E. Q. PILSON. 1983. Nitrogen in estuarine and coastal marine ecosystems. In: Nitrogen in the marine environment. E. J. Carpenter, D. G. Capone (ed.): 565-648. Academic Press, New York.

NOYMA, N. P., L. de MAGALHÃES, L. L. FURTADO, M. MUCCI, F. van OOSTERHOUT \& V. L. M. HUSZAR. 2016. Controlling cyanobacterial blooms through effective flocculation and sedimentation with combined use of flocculants and phosphorus adsorbing natural soil and modified clay. Water Research, 97: 26-38. DOI: 10.1016/j.watre. 2015.11.057

OUDRA, B., M. LOUDIKI, B. SBYYAA, B. SABOUR, R. MARTINS \& A. AMORI. 2002. Detection and variation of microcystin contents of Microcystis blooms in eutrophic Lalla Takerkoust Lake, Morocco. Lake and Reservoirs, Research and Management, 7 (1): 35-44. DOI: 10.1046/j.1440-1770.2002.00165.x

PAERL, H. W. 1998. Nuisance phytoplantkon blooms in coastal, estuarine, and inland waters. Limnology and Oceanography, 33 (4): 823-843. DOI: 10.4319/1o.1988.33. 4 part 2.0823

PAERL, H. W., FULTON, R. S., MOISANDER, P. H. \& J. DYBLE. 2001. Harmful freshwater algal blooms, with an emphasis on cyanobacteria. The Scientific World, 1: 76-113. DOI: 10.1100/tsw.2001.16

PAERL, H. W. 2009. Controlling Eutrophication along the Freshwater-Marine Continuum: Dual Nutrient ( $\mathrm{N}$ and $\mathrm{P}$ ) Reductions are Essential. Estuaries and Coasts, 32 (4): 593-601. DOI: 10.1007/s12237-009-9158-8

PÉREZ-MARTÍNEZ, C. \& P. SÁNCHEZ-CASTILLO. 2001. Temporal occurrence of Ceratium hirundinella in Spanish reservoirs. Hydrobiologia, 452 (1-3): 101-107. DOI: 10.1023/A:1011928027819

PÉREZ-MARTÍNEZ, C. \& P. SÁNCHEZ-CAS- 
TILLO. 2002. Winter dominance of Ceratium hirundinella in a southern north-temperate reservoir. Journal of Plankton Research, 24 (2): 89-96. DOI: 10.1093/plankt/24.2.89

PRÉSING, M., HERODEK, S., VÖRÖS, L. \& I. KOBOR. 1996. Nitrogen fixation, ammonium and nitrate uptake during a bloom of Cylindrospermopsis raciborskii in Lake Balaton. Archiv für Hydrobiologie, 136 (4): 553-562.

PIEHLER, M. F., DYBLE, J., MOISANDER, P. H., CHAPMAN, A. D., HENDRICKSON, J. \& H. W. PAERL. 2009. Interactions between nitrogen dynamics and the phytoplankton community in Lake George, Florida, USA. Lake and Reservoir Management, 25 (1): 1-14. DOI: 10.1080/07438140802714288

QIN, B., ZHU, G., GAO, G., ZHANG, Y., LI, W., PAERL, H. W. \& W. W. CARMICHAEL. 2010. A drinking water crisis in Lake Taihu, China: linkage to climatic variability and lake management. Environmental Management, 45 (1): 105-112. DOI: 10.1007/ s00267-009-9393-6

REYNOLDS, C. S. 1980. Phytoplankton assemblages and their periodicity in stratifying lake systems. Ecography, 3 (3):141-159. DOI: 10.1111/j.1600-0587.1980.tb00721.x

REYNOLDS, C. S. 1984a. Phytoplankton periodicity: the interactions of form, function and environmental variability. Freshwater Biology, 14 (2): 111-142. DOI: 10.1111/j.13652427.1984.tb00027.x

REYNOLDS, C. S. 1984b. The ecology of freshwater phytoplankton. Cambridge Univ. Press, Cambridge and New York. 384 p.

REYNOLDS, C. S. 1996. The plant life of the pelagic. Internationale Vereiningung für Theoretische und Angewandte Limnologie: Verhandlungen, 26 (1): 97-113. DOI: 10.1080/ 03680770.1995.11900695

REYNOLDS, C. S. 2000. Phytoplankton designer - or how to predict compositional responses to trophic-state change. Hydrobiologia, 424 (1-3): 123-132. DOI: 10.1023/A:1003913330889

REYNOLDS, C. S. 2003. The development of preceptions of aquatic eutrophication and its control. Ecohydrology and Hydrobiology, 3 (2): 149-163.

REYNOLDS, C. S. \& D. A. ROGERS. 1976.
Seasonal variations in the vertical distribution and buoyancy of Microcystis aeruginosa Kütz. Emend. Elenkin in Rostherne Mere, England. Hydrobiologia, 48 (1):17-23. DOI: 10.1007/BF00033486

SAADOUN, I. M. K., K. K. SCHRADER \& W. T. BLEVINS. 2001. Environmental and nutritional factors affecting geosmin synthesis by Anabaena sp. Water Research, 35 (5): 1209-1218. DOI: 10.1016/S0043-1354(00) 00381-X

SEDA, J., J. HEJZLAR \& J. KUBECKA. 2000. Trophic stucture of nine Czech reservoires regularly stocked with piscivorous fish. Hydrobiologia, 429 (1-3): 141-149. DOI: 10.1023/A:1004048415779

SMAYDA, T. J. 1980. Phytoplankton species succession. In: The Physiological Ecology of Phytoplankton. I. Morris (ed.): 493-570. Blackwell, Oxford.

SMITH, V. H. 1983. Low nitrogen to phosphorus ratios favor dominance by blue-green algae in lake phytoplankton. Science, 221 (4611): 669-671. DOI: 10.1126/science.221.4611.669

SMITH, V. H., J. SIEBER-DENLINGER, Jr. F. deNOYELLES, S. CAMPBELL, S. PAN \& S. J. RANDTKE. 2002. Managing taste and odor problems in a eutrophic drinking water reservoir. Lake and Reservoir Management, 18 (4): 319-323. DOI: 10.1080/07438140209353938

UTERMÖHL, H. 1931. Neue Wege in der quantitativen Erfassung des Planktons (mit besonderer Berucksichtigung des Ultraplanktons). Verhandlungen Internationalen Vereinigung fü Theoretische und Angewandte Limnologie, 5 (2): 567-596. DOI: 10.1080/03680770.1931. 11898492

VAN GINKEL, C. E., CAO, H., RECKNAGEL, F. \& S. DU PLESSIS. 2007. Forecasting of dinoflagellate blooms in warm-monomictic hypertrophic reservoirs in South Africa by means of rule-based agents. Water $S A, 33$ (4): 531-538.

van LIERE, L. \& A. E. WALSBY. 1982. Interactions of cyanobacteria with light. In: The biology of the cyanobacteria. N. G. Carr \& B. A. Hitton (ed.): 9-45. Blackwell Science Publications, Oxford.

WANG, H. \& H. WANG. 2009. Mitigation of 
lake eutrophication: Loosen nitrogen control and focus on phosphorus abatement. Progress in Natural Science, 19 (10): 1445-1451. DOI: 10.1016/j.pnsc.2009.03.009

WHITTINGTON, J. L., SHERMAN, B., GREEN, D. \& R. L. OLIVER. 2000. Growth of Ceratium hirundinella in a subtropical Australian reservoir: the role of vertical migra- tion. Journal of Plankton Research, 22 (6): 1025-1045. DOI: $10.1093 /$ plankt/22.6.1025

ZHAI, S., YANG, L. \& W. HU. 2009. Observation of atmospheric nitrogen and phosphorus deposition during the period of algal bloom formation in northern Lake Taihu, China. Environmental Management, 44 (3): 542-551. DOI: $10.1007 / \mathrm{s} 00267-009-9334-4$ 